\title{
KEBIJAKAN PEMERINTAH DAN TRADISI MUDIK LEBARAN PADA MASA PANDEMI COVID-19
}

\author{
Oleh: \\ Nuria Febri Sinta Rahayu ${ }^{1}$, Agus Machfud Fauzi ${ }^{2}$, Dinda Ayu Aprilianti ${ }^{3}$ \\ ${ }^{1}$ Universitas Negeri Surabaya; nuriafebri.20017@mhs.unesa.ac.id \\ ${ }^{2}$ Universitas Negeri Surabaya; agusmfauzi@unesa.ac.id \\ ${ }^{3}$ Universitas Negeri Surabaya; dindaayu.20007@mhs.unesa.ac.id
}

\begin{abstract}
ABSTRAK: Penelitian bertujuan untuk mengetahui intensitas kebijakan berupa regulasi dengan tradisi mudik lebaran yang diberlakukan oleh pemerintah pada masa pandemi covid-19 di Desa Wedoro. Teori yang digunakan adalah teori perubahan sosial dari Selo Soemardjan. Pendekatan penelitian menggunakan kualitatif deskriptif dengan jenis penelitian fenomenologi Covid-19. Munculnya fenomena tersebut pemerintah mengantisipasi dengan memberlakukan kebijakan berupa regulasi yang harus dipatuhi oleh masyarakat. Namun, nyatanya masih terdapat beberapa warga yang menyempatkan waktu untuk pulang kampung (mudik). Ketika lebaran tiba, warga di desa Wedoro mengikuti anjuran pemerintah untuk lebaran dirumah saja dan tidak melakukan mudik untuk mencegah penyebaran Covid-19. Hasil penelitian menunjukkan bahwa yang melakukan mudik adalah masyarakat yang mayoritas berkedudukan asli Madura. Dalam tradisi Madura terdapat istilah toren, ketika lebaran tiba, warga berbondong-bondong mudik lebaran. Sehingga tradisi yang melekat pada kelompok masyarakat tidak dapat diubah atau diganggu gugat meski dalam keadaan tertentu pandemi. Mereka menganggap tradisi mudik merupakan hal wajib dilakukan. Berdasarkan fenomena tersebut, perangkat Desa Wedoro mengeluarkan kebijakan bahwa setiap warga yang melakukan kegiatan mudik lebaran maka harus membawa surat keterangan sehat dan bebas Covid-19. melakukan isolasi mandiri di rumah masing-masing selama 1 (satu) minggu. Apabila terdapat warga yang teridentifikasi terpapar Covid-19, maka 1 (satu) keluarga melakukan perawatan inap di Puskesmas terdekat dan mendapat dana bantuan dari desa untuk keperluan sehari-hari. Upaya yang dilakukan pemerintah menimbulkan perubahanperubahan yang mempengaruhi sistem sosial, termasuk pada tatanan pola perilaku masyarakat. Dengan adanya perubahan yang terjadi selalu didasari dengan perencanaan untuk menghasilkan apa yang ingin diwujudkan. Perubahan akan berjalan dengan baik apabila didukung dengan pengendalian atau pengawasan dari yang menghendaki perubahan (agent of change).
\end{abstract}

KATA KUNCI: Kebijakan Pemerintah, Regulasi, Tradisi Lebaran, Pandemi Covid-19

ABSTRACT: The research aims to determine the intensity of policies in the form of regulation with the tradition of Eid al-Fitr homecoming imposed by the government during the covid-19 pandemic in Wedoro Village. The theory used is the theory of social change of Selo Soemardjan. The research approach uses descriptive qualitative with the type of phenomenological research of Covid-19. The emergence of this phenomenon the government anticipates by imposing policies in the form of regulations that must be adhered to by the community. However, in fact there are still some residents who take the time to go home. When Lebaran arrived, residents in Wedoro village followed the government's advice to Eid al-Fitr at home only and did not make homecoming to prevent the spread of Covid-19. The results showed that the homecoming is a society that is 
majority native to Madura. In Madura tradition there is the term toren, when Eid arrives, people flock to Eid al-Fitr. So that the tradition attached to the community can not be changed or contested even in certain circumstances pandemic. They consider the tradition of homecoming a must-do. Based on the phenomenon, wedoro village device issued a policy that every citizen who conducts Eid al-Fitr homecoming activities must bring a certificate of health and free Covid-19. self-isolation in each house for 1 (one) week. If there are residents who have been identified as exposed to Covid-19, then 1 (one) family conducts hospital treatment at the nearest puskesmas and receives assistance from the village for daily needs. The government's efforts to make changes that affect the social system, including the order of patterns of community behavior. With the changes that occur is always based on planning to produce what you want to realize. Changes will run well if supported by control or supervision of who wants change (agent of change).

KEYWORDS: Government Policy, Regulation, Eid Tradition, Covid-19 Pandemic

\section{PENDAHULUAN}

Kabar virus mematikan yang berasal dari Wuhan China ditemukan pada bulan Desember tahun 2019. Menurut beberapa media informasi, virus tersebut dihasilkan oleh pasar hewan yang ada di negara tersebut, sehingga negara China sempat dalam kondisi terpuruk, virus tersebut dikenal dengan nama Covid-19. Setelah Virus tersebut mewabah di negara China, virus tersebut dikonfirmasi telah menyebar ke seluruh negara termasuk di wilayah Asia. Setelah mengetahui hal tersebut, pemerintah Indonesia mengambil tindakan tegas untuk menanggulanginya. Berdasarkan surat edaran yang dikeluarkan oleh pemerintahan pada masa pandemi kini, berbagai kebijakan dibuat dan diberlakukan oleh pemerintah dengan tujuan memutus mata rantai penyebaran Virus Covid-19 yang ada di Indonesia, seperti pemberlakuan kebijakan 3-M, PSBB, dan PPKM. Upaya yangdilakukan oleh pemerintah tersebut semakin diperketat karena setiap harinya angka kasus positif Covid-19 terus bertambah dan angka kematian yang disebabkan virus tersebut juga semakin meningkat.

\footnotetext{
${ }^{1}$ Selo Soemardjan dalam Sosiologi Suatu Pengantar, 2015 (Jakarta: Rajawali Pers, 2015), hlm 261.
}

Keadaan tersebut mengakibatkan keresahan yang terjadi di lingkungan masyarakat, sehingga setiap masyarakat ketika memiliki kepentingan di luar rumah diwajibkan untuk mematuhi protokol kesehatan yang telah diberlakukan oleh pemerintah seperti menggunakan masker, menjaga jarak, dan mencuci tangan. Sehingga keadaan tersebut menimbulkan kebiasaan baru yang terus berulang dan menjadi budaya. Jika dikaitkan dengan budaya baru tersebut maka sama seperti yang dikatakan oleh Louis Althusser mengenai coupure, maksudnya ialah terdapat proses memahami dealektikal materealis akibat adanya suatu problematika.

Kebijakan-kebijakan yang diterapkan di tengah kehidupan masyarakat saat pandemi berlangsung mengakibatkan perubahan sosial. Perubahan sosial yang terjadi karena adanya perubahan pada suatu lembaga yang mempengaruhi sistem serta pola-pola perilaku dalam kelompok masyarakat ${ }^{1}$. Seiring berjalannya kebijakan yang diberlakukan, memunculkan keadaan memaksa terhadap semua masyarakat untuk mematuhi kebijakan-kebijakan dari pemerintah. Namun banyak dari mereka yang belum terbiasa mematuhi protokol 
kesehatan seperti menggunakan masker ketika beraktivitas di luar, dan lain-lain. Perubahan yang terjadi pada masyarakat ini berlangsung tanpa adanya pengawasan masyarakat sehingga menimbulkan dampak yang tidak diharapkan.

Kebijakan dari pemerintah tetap diberlakukan pada setiap elemen masyarakat termasuk pada tingkat desa. Ketika libur lebaran tiba, terdapat regulasi dari desa atas wewenang pemerintah untuk melarang para warga dalam melakukan kegiatan di luar rumah termasuk pada tradisi mudik lebaran yang biasa dilakukan masyarakat pada masa lebaran. Adanya bentuk regulasi yang terdapat di Desa Wedoro terhadap tradisi mudik lebaran merupakan bentuk kebijakan atas penerapan yang diberlakukan dalam pandemi yaitu penerapan 3M, PSBB, dan PPKM. Dengan kondisi tersebut memunculkan adanya larangan dari Presiden RI (Joko Widodo) pada perayaan Hari Raya Idul Fitri 1441 Hijriah yaitu seluruh masyarakat harus tetap berdiam di rumah dan tidak diperbolehkan untuk melakukan mudik atau pulang kampung, kebijakan tersebut diberlakukan sebagai upaya pencegahan penyebaran virus Covid-19. Dengan larangan tersebut, maka Menteri Perhubungan mengeluarkan kebijakan mengenai pengendalian pada semua transportasi selama musim mudik lebaran untuk mencegah penyebaran virus Covid-19 berlangsung (Permenhub No. 25 Tahun 2020).

Dalam kebijakan Permenhub yang diedarkan terdapat larangan yang menerapkan sanksi tercantum dalam UU Pasal 93 Tahun 2018 yang berisi tentang kegiatan karantina kesehatan kepada seluruh masyarakat, dan apabila ada suatu pelanggaran pada karantina kesehatan maka nantinya dikenakan pidana satu tahun penjara dan denda maksimal $\mathrm{Rp}$.
100 juta. Pada proses pelanggaran nantinya ada tahapan berupa teguran secara persuasif hingga sanksi berat sesuai dengan UU Pasal 93 Tahun 2018. Namun berdasarkan fenomena yang terlihat pada saat libur lebaran tahun 2020 yang lalu, adanya regulasi yang diterapkan di Desa Wedoro berdasarkan kebijakan pemerintah tidak mengubah pemikiran para warga untuk melakukan kebiasaannya yaitu pulang kampung pada masa pandemi meski adanya sanksi kebijakan yang telah diberlakukan pemerintah kepada warga yang memaksa melakukan mudik. Maka dengan demikian, pemerintah harus bekerja sama dengan tatanan-tatanan struktur dalam pemerintahan mulai dari setiap provinsi, kabupaten, kecamatan, sampai ke daerah untuk lebih memperketat dan menegakkan kembali hukum yang berlaku.

Adanya kebijakan mengenai larangan budaya pulang kampung memberikan asumsi positif maupun negatif dari masyarakat karena diantara mereka ingin berkumpul dengan sanak saudaranya, sedangkan disisi lain dengan kegiatan yang dilakukan di luar rumah dapat memicu penyebaran angka Covid19. Di daerah Jawa Timur terdapat kenaikan angka Covid-19 tertinggi setelah Jakarta. Dengan demikian maka Gubernur Jawa Timur menghimbau kepada semua daerah Jawa Timur untuk menyediakan tempat layanan observasi atau isolasi mandiri hingga di tingkat desa karena berdasarkan prakiraan nantinya terdapat fenomena perlonjakan angka pulang kampung pada masyarakat. Adanya regulasi yang telah dirancang oleh pemerintah masih terus diabaikan oleh masyarakat, sehingga untuk mengantisipasinya pemerintah membuka pintu kepada para pemudik untuk pulang kampung dengan cara memenuhi persyaratan yang dibuat seperti kebijakan 
protokol kesehatan sesuai anjuran dan berdasarkan persyaratan dari pemerintah.

Persyaratan tersebut antara lain: (1) Para pekerja pada bidang pertahanan, keamanan, dan ketertiban umum, kesehatan, kebutuhan dasar, fungsi ekonomi, hingga percepatan penanganan Covid-19. (2) Pasien yang membutuhkan penangan mesdis. (3) Masyarakat yang memiliki kebutuhan mendesak. (4) Para pemulangan PMI, WNI, dan pelajar dari luar negeri untuk pulang ke daerah asal. Dengan adanya kebijakan-kebijakan yang telah dupayakan maka diharapkan masyarakat selalu memperhatikan dan mematuhi kebijkan tersebut, sehingga dapat memutus mata rantai penyebaran Covid-19.

\section{METODE}

Penelitian ini menggunakan metode kualitatif deskriptif yang dalam penjelasannya mengacu pada definisi yang diperoleh dari pandangan masyarakat. Berdasarkan pendapat Sugiyono (2005) bahwa metode deskriptif merupakan metode yang digunakan untuk menggambarkan atau menganalisis hasil dari penelitian yang dilakukan tetapi tidak digunakan untuk menyimpulkan secara luas. Sehingga nantinya data yang diperoleh dari metode ini berdasarkan dengan realita yang terjadi di lapangan.

Metode pengambilan data adalah wawancara $^{2}$ dan observasi ${ }^{3}$. Metode wawancara dan observasi ini memiliki keunggulan yaitu tidak ada hasil rekayasa. Untuk penelitian ini objeknya adalah warga Wedoro Kec. Waru Kab. Sidoarjo yang dilakukan dengan cara purposive sampling. Dalam metode pengumpulan data, peneliti menggunakan dokumentasi sebagai

\footnotetext{
${ }^{2}$ Wawancara adalah kegiatan tanya jawab untuk mendapatkan keterangan atau pendapat mengenaisuatu hal. (KBBI)
}

pendukung, untuk selanjutnya melakukan wawancara dan observasi mendalam dengan pertanyaan-pertanyaan yang telah disusun dan dikembangkan, lalu selanjutnya dilakukan pengolahan dan konsolidasi data, guna penelitian tersebut menghasilkan data yang akurat dan bisa menjamin keasliannya. Untuk menguatkan penelitian ini terdapat beberapa data yang diambil dari media sosial seperti media televisi, instagaram, maupun twitter.

Metode ini dilakukan untuk menganalisis regulasi di Desa Wedoro Kec. Waru dengan budaya pulang kampung saat lebaran dengan kebijakan pemerintah (3M-PSBB) yang berlaku di tahun 2020. Penelitian ini menggunakan teori perubahan sosial dari Selo Soemardjan yang mengatakan bahwa terjadinya perubahan sosial terjadi pada suatu kelembagaan di masyarakat yang mempengaruhi aspek-aspek soail seperti nilai, sikap, pola perilaku, dan sistem sosial yang ada di masyarakat. Adanya regulasi yang di tegakkan oleh aparat pemerintah dan dibantu dengan pegawai daerah guna memutus mata rantai penyebaran Covid-19 ini memberikan perubahan sosial yang cukup luas.

\section{HASIL DAN PEMBAHASAN}

\section{Kebijakan Regulasi pada Masa Pandemi}

Kabar tentang hadirnya virus Covid-19 yang berasal dari Wuhan China disebut virus yang mematikan telah didengar sejak bulan Desember 2019, keadaan tersebut sempat membuat geger seluruh negara di dunia, salah satunya di Indonesia. Tidak lama kemudian kabar virus pandemi tersebut menyebar sampai di Indonesia dan memberikan

\footnotetext{
${ }^{3}$ Observasi adalah tinjauan atau pengamatan secara spesifik. (Sugiyono, 2017: 203)
} 
kekhawatiran, pasalnya dikemudian hari terdapat beberapa warga yang terindikasi terkena virus Covid-19. Adanya pandemi tersebut menjadi masalah sosial dan mengakibatkan perubahan pola perilaku masyarakat hingga saat ini. Berbagai aspek kehidupan telah mengalami perubahan yang sangat signifikan, karena selang beberapa waktu angka kematian yang diakibatkan oleh virus tersebut terus meningkat.

Pemerintah masih terus berupaya untuk megatasi permasalahan tersebut mulai dari penerapan $3 \mathrm{M}$ kemudian penerapan PSBB yang mengalami perpanjangan hingga saat ini diubah dengan penerapan PPKM. Kebijakan 3M merupakan kebijakan yang wajib dilakukan yaitu dengan mencuci tangan dengan air yang mengalir, memakai masker, dan menjaga jarak dari kerumunan. Kebijakan tersebut disahkan oleh pemerintah pada awal September dalam surat edaran dari Sekertaris Jendral Kemendikbud No. 77106/A.A7/EP/2020.

Kebijakan 3M disaranakan untuk diterapkan ketika beraktivitas di dalam maupun di luar rumah, akan tetapi hal tersebut menimbulkan pendapat prokontradi masyarakat, pasalnya beberapa masyarakat berpendapat apabila kegiatan di dalam rumah tidak menimbulkan kerumunan. Kebijakan 3M terus dioptimalkan dan diperketat sehingga muncul kebijakan baru yaitu 5M. Penerapan 5M ini merupakan pengganti dari kebijakan 3M.

5M yang dimaksud di sini ialah: (1) Memakai Masker; Diharapkan kepada seluruh masyarakat untukmenggunakan masker saat berkegiatan diluar rumah ataujuga saat berku mpul dengan kerabar di manapun tempatnya. (2) Mencucui Tangan; Setiap orang perlu melakukan cuci tangan menggunakan sabun dan air yang mengalir secara bersih. Apabila tidak memungkinkan untuk bercuci tangan maka yang harusdilakukan ialah menggunakan hand sanitizer yang berbahan dasar alkohol agar bersih dari kuman-kuman yang menempel pada tangan dan area sekitarnya. (3) Menjaga Jarak; Apabila anda melakukan kegiatan di luar rumah maka yang perlu diperhatikan adalah dengan menjaga jarak dengan orang sekitar. Dalam anjuran untuk menjaga jarak ialah satu sampai dua meter. (4) Menjauhi Kerumunan; Dalam kegiatan yang dilakukan di luar rumah yang sangat penting adalah menjauhi kerumunan, karena saat berkerumun ada kontak fisik yang tidak berjarak sehingga dapat dimungkinkan lebih cepat jika terpapar dengan virus Covid-19. (5) Mengurangi Mobilitas Mobilitas yang dimaksud ialah pergerakan yang dilakukan oleh masyarakat untuk keluar rumah. Dan diharapkan masyarakat tidak perlu keluar rumahapabila tidak dalam keadaanyang mendesak dan penting.

Penerapan 5M sama halnya dengan 3M, akan tetapi pemerintah meningkatkan kembali kebijakan yang ada sebelumnya guna masyarakat lebih memperhatikan dan peduli dengan kesehatan yang ada pada dirinya. Dalam penerapan PSBB terdapat berbagai regulasi yang diterapkan dan telah tercantum pada Peraturan PemerintahNo. 21 Tahun 2020 mengenai Pembatasan Sosial Berskala Besar atau PSBB dalam rangka percepatan untuk penangan virus Corona-19, kemudian Peraturan Menteri Kesehatan No. 09 Tahun 2020 mengenai pedoman dalam Pembatasan Sosial Berskala Besar atau PSBB, dan Peraturan Pemerintah Pengganti Undang-Undang atau Perpu No. 01 Tahun 2020 mengenai Kebijakan Keuangan Negara dan Stabilitas Sistem Keuangan Untuk Penanganan dari pandemi Covid-19 dalam menghadapi rintangan yang membahayakan sektor perekonomian di Indonesia. Penerapan kebijakan PSBB yang ditekankan oleh Presiden RI yaitu, 
Joko Widodo pada tanggal 31 Maret 2020. Akan tetapi baru direalisasikan pertama kali di daerah ibukota Jakarta pada tanggal 10 April 2020. Dan kemudian, di ikuti oleh daerah-daerah yang lain seperti Sumatera Barat, Tangerang, termasuk di daerah Sidoarjo, Surabaya, dan Gresik.

$\begin{array}{rlr}\text { Saat } & \text { penerapan } & \text { PSBB } \\ \text { berlangsung } & \text { berbagai } & \text { kegiatan }\end{array}$ diberhentikan untuk sementara waktu, seperti kegiatan belajar tatap muka di sekolah, jual-beli di pasar atau pertokoan, pemberhentian kegiatan pariwisata, dan kegitan yang melibatkan fasilitas umum. Namun terdapat pengecualian yang melibatkan delapan sektor dalam kebutuhan manusia. Seperti sektor kesehatan, sektor pangan, sektor keuangan, dan sektor komunikasi. Dengan adanya regulasi yang telah dikeluarkan oleh pemerintahan maka pihak Kepolisian menindak lanjuti dengan Maklumatnya pada No. Mak/2/III/2020 mengenai Kepatuhan Masyarakat Dalam KebijakanPemerintah guna memutus mata rantai penyebaran Covid-19 dalam kegiatan PSBB.

Adanya maklumat tersebut untuk mengatasi pelanggaran yang dilakukan oleh masyrakat. Di daerah Sidoarjo, Surabaya, dan Gresik juga menerapkan kebijakan PSBB yang di perintahkan oleh Gubernur Jawa Timur, sehingga desadesa yang ada pada daerah tersebut mendapatkan regulasi dari pemerintah yang harus ditaati.

PSBB yang diberlakukan oleh Gubernur Jawa Timur terbagi menjadi dua jilid. Pada jilid I dilakukan pada tanggal 20April 2020. Beliau membuat kebijakan tersebut berdasarkan dengan surat edaran Menteri Kesehatan No. 09 Tahun 2020 mengenai Pedoman PSBB untuk Percepatan Penanganan Kasus Covid-19. Kebijakan tersebut dilakukan dengan dibantu oleh aparat kepolisian untuk mengawasi mobilitas yang ada pada masyarakat. PSBB yang dilakukan yaitu dengan waktu 24 jam sehingga terdapat pelaksanaan jam malam pada pukul 21.00 WIB seluruh warga tidak boleh ada yang beraktivitas di luar rumah.

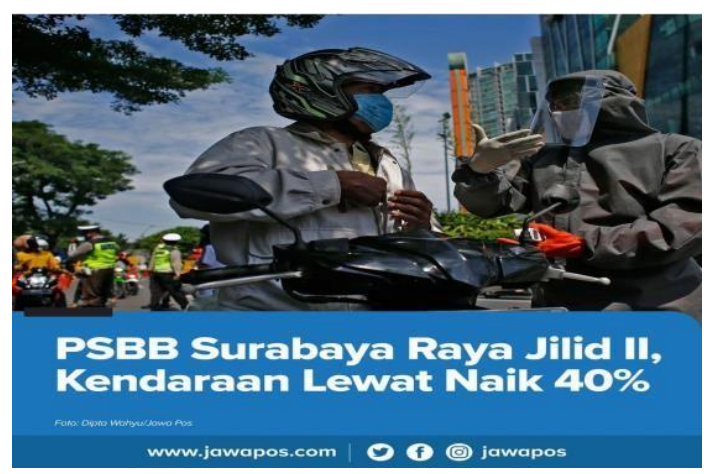

Gambar 1.

(Sumber:https://www.instagram. com/p/CAH1 xwnAra7/?ighsid=6jirwvu2 $\underline{\mathrm{n}}$

9e7https://www.instagram.com/p/B _wQ pFKgLeS/?ighsid=19grd2d9hwolk)

Pada jilid II dilakukan pada tanggal 12 Mei 2020 dan kembali beroperasi dalam waktu 24 jam hingga dua pekan ke depan dengan kebijakan dan sanksi yang diperketat sebagai konsekuensinya saat melanggar. Dalam memperketat regulasi yang bersinambungan ini maka dilakukan operasi pada jam malam dalam waktu 24 jam di tempat-tempat umum. Seperti, pasar, fasilitas umum, persimpangan jalan besar, dan pabrik industri. (Heru Tjahjono, 2020). Dalam kebijakan ini, Gubernur Jawa Timur meminta untuk memberlakukan physical distancing pada fasilitas umum, dan pemberlakuan pada oprasi ganjil-genap. Untuk sanksi yang diberikan bagi setiap pelanggar yaitu tidak dapat melakukan perpanjangan SIM dan SKCK karena pihak keamanan dapat melakukan penahanan pada KTP pelanggar.

Berdasarkan data yang diperoleh, para pelanggar PSBB di jilid II dapat terancam Undang-Undang Pidana, Pasal 
216 KUHP dan ancaman hukuman penjara selama empat bulan dua minggu ${ }^{4}$. Pada kenyataannya, PSBB jilid II masih terdapat kelonjokan kendaraan khususnya pada roda dua yakni $40 \%$.

\section{Lebaran pada Masa Pandemi}

Pada tahun-tahun sebelumnya dengan mudah kita dapat melakukan kegiatan di luar rumah atau berlibur dan mudik dengan sesuka hati tanpa adanya regulasi yang mengikat. Namun, pada tahun 2020 semua kegiatan yang ingin dilakukan sangat terbatas dan sangat terikat dengan kebijkan-kebijakn dari pemerintah. Salah satunya saat lebaran tiba, lebaran di tahun 2020 menjadi lebaran yang berbeda. Berdasarkan dengan regulasi yang telah diberlakukan oleh pemerintah maka disaat lebaran pemerintah menghimbau kepada seluruh masyarakat untuk tetap merayakan lebaran dengan di rumah saja, dan sesuai dengan anjuran pemerintah untuk tetap mematuhi protokol kesehatan melalui 3M, PSBB, dan sampai sekarang yaitu PPKM. Masyarakat tidak dapat melakukan kegiatan halal bi halal dengan sanak famili bahkan tetangga sekitar rumahnya.

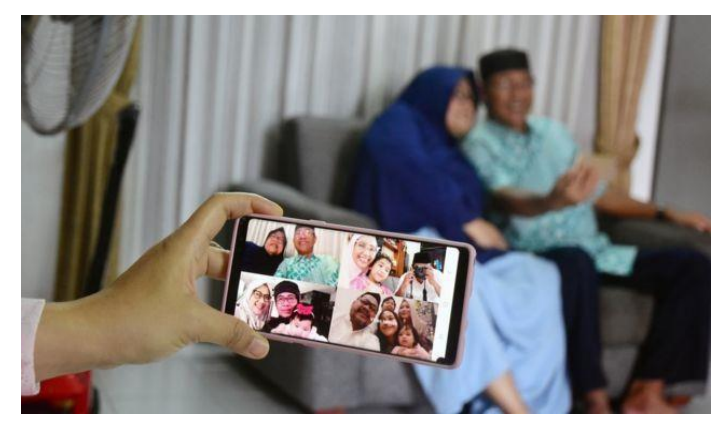

Gambar 2.

(Sumber:https://www.bbc.com)
Berdasarkan fakta yang terjadi di lapangan sebagaian basar masyarakat memanfaatkan teknologi untuk dapat bersilaturrahmi melalui virtual online. Mereka hanya dapat bertemu dan memaafkan satu sama lain secara tidak langsung atau tatap muka via online. Adanya dukungan dari aplikasi digital yang dapat diakses melalui benda elektronik seperti telepon genggam dan laptop sudah bukan menjadi alasan untuk tidak dapat berkomunikasi satu sama lain. Sehingga pada masa pandemi ini semua elemen masyarakat hanya bisa mengandalkan dari aplikasi tersebut untuk melakukan kegiatan yang membutuhkan tatap muka.

Selain itu, saat halal bi halal lebaran sebagian masyarakat juga menolak adanya tamu yang berkunjung ke rumah. Dan budaya yang ada untuk berbagai angpao mereka berikan dengan cara yang unik, seperti di daerah Waru dan Karangrejo. Sebagian dari mereka berpendapat bahwa adanya kebijakan dari pemerintah tidak mengubah bentuk kesakralan untuk merayakan lebaran bersama dengan keluarga.

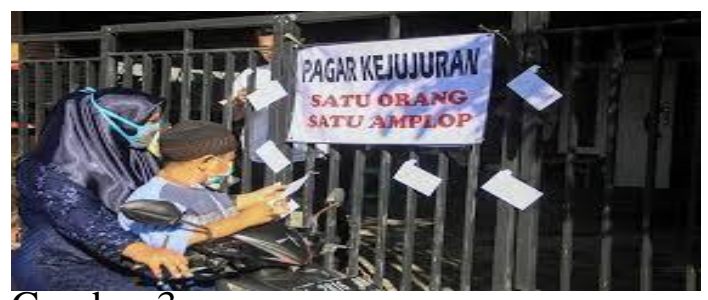
Gambar 3.

(Sumber:https://www.viva.co.id/berita/na sional.com)

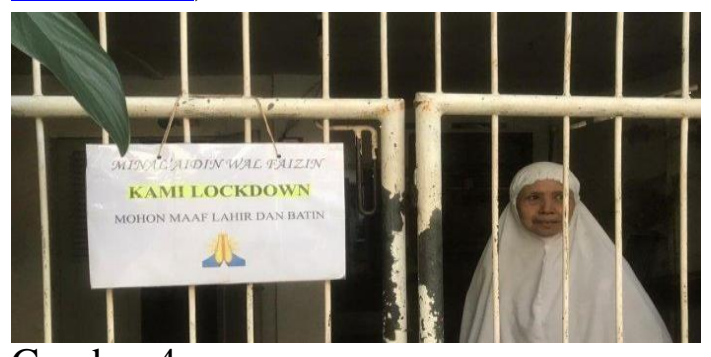

Gambar 4.

(Sumber: Tribun Jawa Timur Travel)

\footnotetext{
${ }^{4}$ Pemkot Bogor UU KUHP, Pasal 216.
} 


\section{Tradisi Mudik Lebaran pada Masa Pandemi}

Tradisi saat lebaran sangat melekat pada setiap masyarakat. Jika dilihat di lapangan sebagian masyarakat di Desa Wedoro merupakan penduduk urbanisasi dari desa ke kota dan menetap untuk menempuh kehidupan baru yang layak. Sehingga, mayoritas dari mereka setiap libur lebaran tiba melakukan kegiatan pulang kampung. Namun berbeda dengan lebaran di tahun 2020 . Berdasarkan peraturan dari Kementerian Perhubungan yang telah diresmikan, pada Permenhub No. 25 Tahun 2020 mengenai pengendalian transporatsi guna mencegah penyebaran kasus Covid-19. Larangan tersebut baik dalam sarana transportasi darat, laut, maupun udara, baik transportasi umum maupun transporatsi pribadi. Akan tetapi terdapat pengecualian pada transporatsi yang ada seperti, kendaraan dinas, kendaraan TNI atau Polri, kendaraan ambulans atau jenazah, dan kendaraanyang mengangkut barang logistik.

Mayoritas dari masyarakat memangmematuhi kebijakan yang telah disahkan oleh pemerintah. Akan tetapi masih ada beberapa masyarakat yang belum mampu mengikuti kebijakan tersebut sehingga nekat untuk melakukan kegiatan mudik lebaran. Termasuk di daerah Wedoro, beberapa warga yang berasal dari Madura mengikuti tradisi toron dan banyak yang melakukan mudik saat lebaran sehingga menimbulkan kepadatan area jembatan Suramadu akibat lebaran tiba. Adanya peraturan dari pemerintah sebagian kecil dilanggar oleh masyarakat yang mengenal tradisi sehingga melupakan regulasi yang dapat menimbulkan konsekuensinya.

\footnotetext{
${ }^{5}$ Selo Semardjan, op.cit., hlm. 381 dan seterusnya.
}

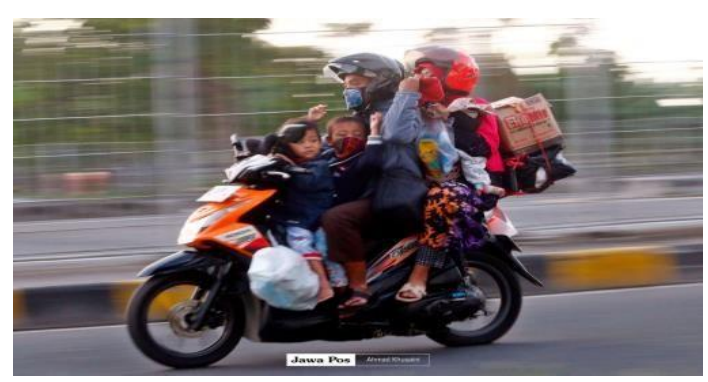

Gambar 5.

Masyarakat mudik dengan melintasi jembatan Suramadu.

(Sumber: Instagram Jawa Pos)

Dengan kondisi yang diakibatkan oleh kebijakan-kebijakan dari pemerintah guna memutus mata rantai penyebaran Covid-19 masyarakat mau tidak mau dipaksa untuk mengikuti peraturan yang sifatnya hukum. Peraturan merupakan tujuan dari kehendak yang diingonkan oleh sesorang, lembaga, atau yang lain.

Peraturan mengandung makna yang kukuh, tidak dapat di goyangkan dan memaksa. Sehingga semua wajib untuk mentaati peraturan yang ada dalam masyarakat. Berdasarkan dengan fenomena di lapangan, terdapat perubahan-perubahan yang terjadi pada masyarakat sehingga mempengaruhi pola perilaku yang ada.

Perubahan yang dilakukan pemerintah dan diterapkan di masyarakat merupakan bentuk perubahan yang dikehendaki (Itended-Change), dalam perubahan ini terdapat perencanaan yang sudah dipikirkan matang oleh pihak pemerintah $^{5}$. Pasalnya semua kebijakan yang ada tidak seperti yang diinginkan oleh sebagian masyarakat. Mayoritas dari mereka menginginkan untuk melakukan tradisi mudik lebaran akan tetapi pada realitasya semua kegiatan masyarakat diatur oleh pemerintah. Menurut teori Unilinear theoris of evolution ${ }^{6}$ teori ini

\footnotetext{
${ }^{6}$ Inkeles Alex, What Is Sociology (New Delhi: Prentice Hall Of India, 1965), hlm, 31.
} 
berpendapat bahwasanya manusia dan masyarakat dapat mengalami perkembangan dalam perubahan melalui proses bertahap (August Comte, Herbert Spencer).

Terwujudnya kesempurnaan dalam mematuhi kebijakan protokol kesehatan maka masyarakat dan budaya perlu bekerjasama dengan tahapan proses dari yang sederhana, kemudian kompleks sehingga muncul kesempurnaan dalam masyarakat. Kebijakan tersebut dengan mengubah pola perilaku masyarakat agar lebih berhati-hati dan sangat menjaga kesehatan. Dengan dibantu penerapan 3M, PSBB, dan PPKM masyarakat dapat membentuk perubahan. Sehingga angka kasus yang tadinya mencapai 1000 sekarang menjadi 800-an. Adanya keberhasilan tersebut karena berada di bawah pengawasan ${ }^{7}$.

Masyarakat di desa Wedoro mengalami pola perubahan dalam berperilaku. Ketika terbiasa dengan jam malam pada pukul 21.00 - 04.00 WIB, maka semua tempat terasa sunyi tidak seperti sebelumnya. Kegiatan-kegiatan seperti ibu-ibu PKK sudah tidak melakukan kegiatan yang biasa dilakukan dengan berkerumun, namun kegiatan yang dilakukan untuk bertemu hanya ketika mengurus keuangan PKK saja. Lalu segerombol ibu-ibu rumah tangga yang sering melakukan kegiatan seperti merumpi, saat ini sudah tidak terjadi.

Masyarakat saat ini dibandingkan dengan sebelumnya sangat berbeda. Yakni yang sebelumnya tidak memperdulikan kesehatannya, saat ini lebih memperdulikan kesehatannya seperti sering mencuci tangan ketika keluar-masuk ruangan, jarang berkerumun dengan orang-orang yang tidak dikenal, tidak melakukan kegitan di luar rumah apabila tidak ada kepentingan

${ }^{7}$ Ibid., hlm 380, 381. yang mendesak. Malah sebaiknya, kebiasaan-kebiasaan yang diupayakan oleh pemerintah kini melekat dalam kesehariannya. Seperti saat lebaran yang lalu masyarakat dinilai $85 \%$ mengalami ketertiban dalam kebijakan pemerintah. Sehingga, hanya sebagian kecil dari masyarakat yang masih bertekad untuk berkegiatan di luar rumah.

\section{PENUTUP}

Segala upaya yang telah dilakukan pemerintah untuk memutus mata rantai penyebaran Covid-19 dapat dikatakan sudah membawa hasil. Pernyataan tersebut dibuktikan dengan data bahwa terdapat tiga provinsi yang memiliki penurunan angka kasus Covid19, yaitu Jawa Tengah, Jawa Timur, dan Sulawesi Selatan ${ }^{8}$. Namun tidak berhenti di situ, pemerintahterus berupaya untuk mewujudkan tujuan yang diinginkan meski berbagai perubahan terjadi dari berbagai aspek. Pemerintah juga menghimbau untuk perangkat desa memperketat kembali kebijakan yang diberlakukan khususnya saat libur lebaran tiba.

Ketika lebaran tiba, warga di Desa Wedoro mengikuti anjuran pemerintah untuk lebaran di rumah saja dan tidak melakukan mudik lebaran untuk mengurangi penyebaran kasus Covid-19. Namun berdasarkan penelitian yang melakukan mudik lebaran ialah masyarakat yang mayoritas berkedudukan asli Madura. Dalam tradisi Madura terdapat istilah toren yang dimana ketika lebarantiba, maka semua warga berbondongbondong untuk melakukan kegiatan mudik lebaran. Sehingga tradisi yang melekat dalam suatu kelompok masyarakat tidak dapat diubah atau diganggu gugat meski dalam keadaan

${ }^{8}$ Kementrian Kesehatan Republik Indonesia Jakarta, 21 Oktober 2010. 
tertentu. Karena menurut sebagian besar dari mereka tradisi merupakan hal wajib yang perlu dilakukan. Sehingga tradisi yang melekat dalam suatu kelompok masyarakat tidak dapat diubah atau diganggu gugat meski dalam keadaan tertentu. Karena menurut sebagian besar dari mereka tradisi merupakan hal wajib yang perlu dilakukan.

Berdasarkan fenomena tersebut, para pihak perangkat Desa Wedoro memberikan kebijakan di desa, bahwa setiap warga yang melakukan kegiatan mudik lebaran maka harus membawa surat keterangan ehat dan bebas dari Covid-19. Dan melakukan isolasi mandiri di rumah masing-masing selama satu minggu. Apabila terdapat warga yang teridentifikasi terpapar kasus Covid-19 maka satu keluarga melakukan perawatan inap di Puskesmas terdekat dan mendapat dana bantuan dari desa untuk kesehariannya.

Segala upaya yang dilakukan pemerintah menimbulkan perubahanperubahan yang mempengaruhi sistem sosial dan termasuk pada tatanan pola perilaku masyrakat ${ }^{9}$. Dengan adanya perubahan besar yang terjadi selalu didasari dengan perencanaan untuk menghasilkan apa yang ingin terwujud dan perubahan akan berjalan dengan baik apabila didukung dengan pengendalian atau pengawasan dari yang menghendaki perubahan (agent of change).

\section{DAFTAR PUSTAKA}

Abdurrahman Al-Farid https://tribunnewswiki.com/202 0/05/08/kabar-gembira-inilah-4syarat-orang- diperbolehkanpulang-kampung-saatlarangan-mudik-siapasaja?page $=2$ Sabtu,9 Mei 2020
03.52 WIB. Diakses pada tanggal 16 Februari 2021

Andika Dian. 2020. "Dampak Pelarangan Mudik Akibat Pandemi Covid19 Terhadap Bisnis Angkutan Udara di Indonesia". Journal of CivilEngineering and Planning. Hal, 119-121. Vol. 1, No. 2.

Aunillah, Rinda. July 2020.

"Determinisme Teknologi:

Perayaan Idul fitri di Sat Pandemi”. Fakultas Ilmu Komunikasi, Universitas Padjadjaran. Hal, 5-8 Vol. 3, No. 1

Harto Ambrosius.

https://www.kompas.id/baca/nu santara /2020/05/19/laranganmudik-masih- diabaikan-dijatim/ 19 Mei 202011: 33WIB. Diakses pada tanggal15 Februari 2021.

Mujani Saiful, Irvani Deni. 20 Oktober 2020. "Sikap dan Perilaku Wabah Terhadap Kebijakan Penanganan Wabah Covid-19”. Jurnal Ilmu Politik. Hal, 227230. Vol. 11 No.2.

Naim, Ngainun. 2020. Lebaran di Tengah Pandemi (1) "Nuansa Idul Fitri di Tengah Corona". Tulungagung: IAIN Tulungagung Press. E-book.

Rusli Cahyadi M.Si. http://lipi.go.id/berita/single/Sur vei- Ketahanan-SosialMasyarakat-selamaPSBB/22050 11 Januari 2020. Diaksespada tanggal 15 Februari 2021.

Tribun Jawa Timur, 2020 www.tribunjatim.comuTidak

$\begin{array}{lrr}\text { Menerima } & \text { Tamu } & \text { Untuk } \\ \text { Berkunjung } & \text { diakses } & \text { pada } 05 \\ \text { Maret 2021. } & & \end{array}$

\footnotetext{
${ }^{9}$ Social Change in Yogyakarta, 1962. (New York:

Cornell University Press, Itacha), hlm, XVIII dan 379
} 
74 _Kebijakan Pemerintah dan Tradisi Mudik Lebaran pada Masa Pandemi ..., Nuria Febri Sinta Rahayu, dkk

Utami Intan, Ertanto Dody. Agustus

Lebaran Di Tengah Covid-19"

Jurnal Penelitian Manajemen

Pendidikan Islam. Hal, 132-

138. Vol. 5, No. 2. 